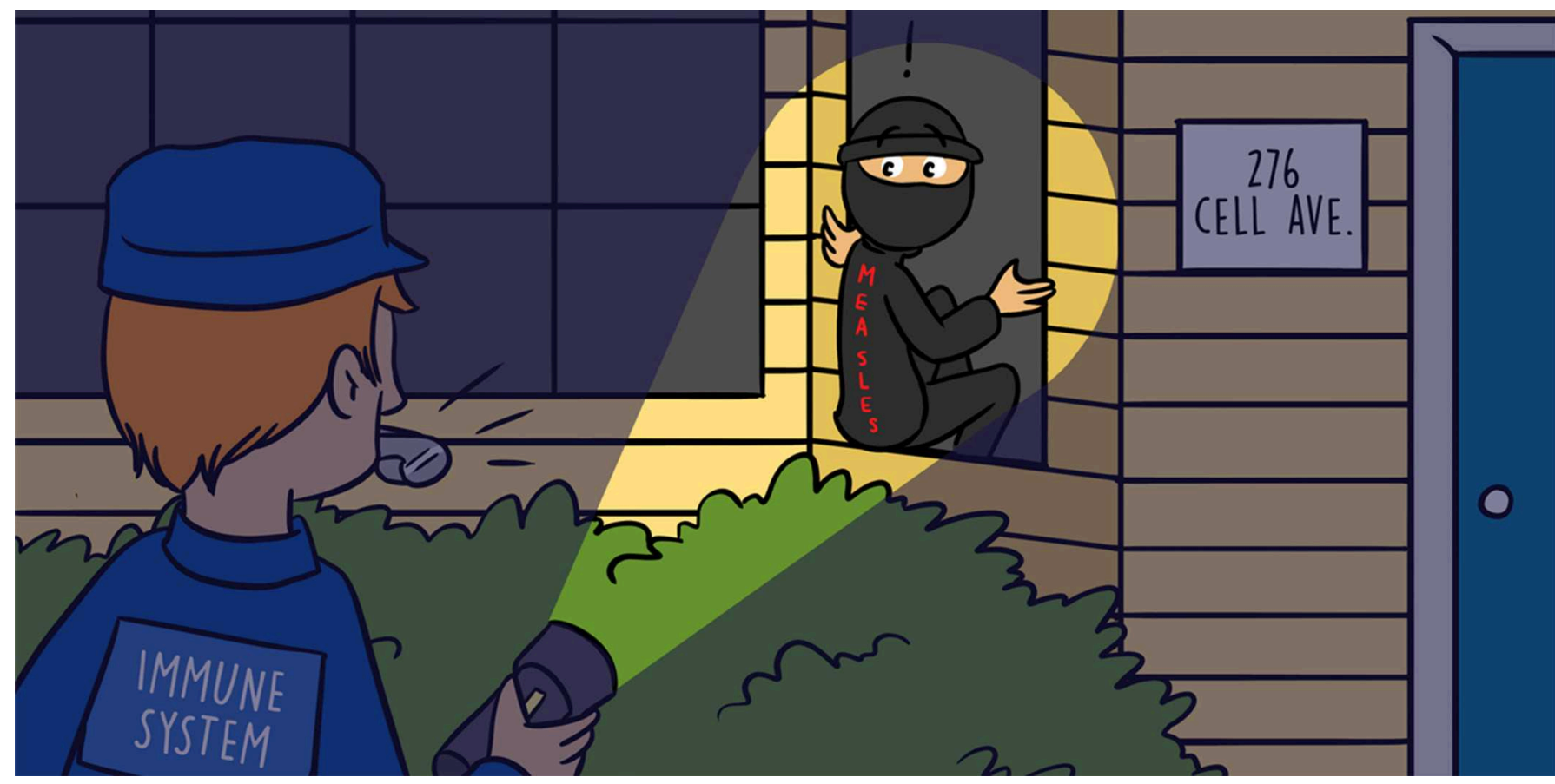

\title{
WHY IS MEASLES VACCINATION SO IMPORTANT?
}

Emma Slack ${ }^{1 *}$, Markus Arnoldini ${ }^{1}$, Daniela Latorre ${ }^{2}$, Selma Aslani ${ }^{3}$, Valentina Biagioli ${ }^{3}$, Tania Cruz ${ }^{3}$, Naomi Elina Dünki ${ }^{3}$, Antonia Chiara Jeanne Eichelberg ${ }^{3}$, Matthias Goldiger ${ }^{3}$, Nicole Howald ${ }^{3}$, Giovanni Marastoni ${ }^{3}$, Thierry Marti ${ }^{3}$, Vega Peterhans ${ }^{3}$, Lavanja Selvakumar ${ }^{3}$ and Anna Winterberg ${ }^{3}$

${ }^{1}$ Institute for Food, Nutrition and Health, ETH Zurich, Zurich, Switzerland

${ }^{2}$ Institute for Microbiology, ETH Zurich, Zurich, Switzerland

${ }^{3}$ ETH Zurich, Zurich, Switzerland

YOUNG REVIEWERS:

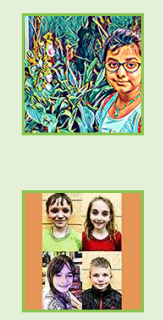

ALAA

AGE: 11

FRIESS

LAKE

ELEMENTARY

AGE: 9
Measles is a dangerous and nasty disease caused by the measles virus. The virus spreads quickly from person to person, and there is no cure. A successful vaccine had almost completely eliminated the disease from America and Europe. Unfortunately, due to scare-stories and fake news, many people stopped getting the vaccine. This has allowed the disease to come back. Here we explain: (1) what measles is; (2) how the vaccine works; and (3) why the scare-stories are not true.

\section{WHAT IS MEASLES?}

Do you remember the last time you were sick? Maybe you had pain or a fever? Maybe every noise and touch felt horrible? Maybe you could not sleep, or you could not stay awake? You may have experienced these feelings a few times in your life, due to different infections. Measles is a particularly bad infection. It causes a high fever, a bad cough, red and itchy eyes, and a red, flat skin rash. If you are lucky, the symptoms 


\section{VACCINE}

A weakened or dead microorganism, or a part of a microorganism, that can train the immune system to recognize and defend the body against the actual microorganism.

\section{VIRUS}

Tiny microorganism that can only grow inside the cells of another organism. Some viruses can infect human cells and cause disease.

\section{MICROORGANISM}

A life-form that is very small and cannot be seen with the naked eye, only with a powerful microscope. Bacteria and viruses are microorganisms

\section{IMMUNE SYSTEM}

The system in the body that protects it from microorganisms. Some parts of the immune system can be trained by vaccines to recognize infectious microorganisms. start to go away after about 10 days. In really severe cases, measles infection can spread to the lungs and brain, leading to death [1]. In the late 1990s, measles had been almost completely wiped out from the western world because of a successful vaccine. However, due to fake news, not enough people are vaccinated today, and the disease is coming back.

Measles cannot be cured. The only thing we can do for people who are sick with measles is to treat the signs of their illness, for example reducing their fever and keeping them hydrated. This means that the only way to avoid getting sick from measles is to not get it in the first place.

Measles can be spread through coughs, sneezes, and saliva from other people who are sick with measles. The measles virus causes this disease. A virus is an extremely small microorganism that invades the body. Different viruses also cause diseases, such as chicken pox and flu. Imagine the virus as a burglar and the human cell as a house. The burglar enters the house and uses everything in it to make a bunch of copies of himself. This destroys the house. After destroying the house, every single burglar-copy invades a new house and the cycle begins again. Eventually the entire city (your body) gets damaged. This damage to cells makes you feel sick.

\section{HOW DOES THE MEASLES VACCINE WORK?}

Luckily, your body has a police force called the immune system. The immune system patrols the body day and night to catch all kinds of bad microorganisms, such as the viruses or bacteria that cause infections. Each one of these microorganisms (for example the chicken pox virus, the flu virus, and the measles virus) uses different tools to infect us, and therefore the immune system police need specific training to recognize and "arrest" each different microorganism.

More than 200 years ago, scientists realized that the immune system could be trained to recognize dangerous microorganisms. This training can happen if the body encounters weakened versions of the microorganisms that are not capable of making the person sick-this is the idea of a vaccine. Vaccines look identical to the real virus or bacteria, but they are changed in the lab to make them weak so they cannot cause disease. The measles vaccine has been changed so that it cannot copy itself properly [2]. When you get the measles vaccine, your immune system sees and investigates this weakened virus and the weak virus in the vaccine does not damage your cells. This vaccination trains the immune system to recognize and "arrest" the real measles virus, if you ever come into contact with it.

In fact, you can think of this immune system training as the police developing a special type of handcuffs that exactly fit the measles 


\section{Figure 1}

The measles vaccine trains the immune system to produce anti-measles antibodies. (A) The immune system recognizes the vaccine. (B) Antibodies are produced that bind to the measles virus. (C) If you encounter the actual measles virus, it is immediately arrested by antibodies!

\section{ANTIBODY}

When your immune system encounters a microorganism, it generates proteins able to precisely bind to the microorganism. These proteins are called antibodies.

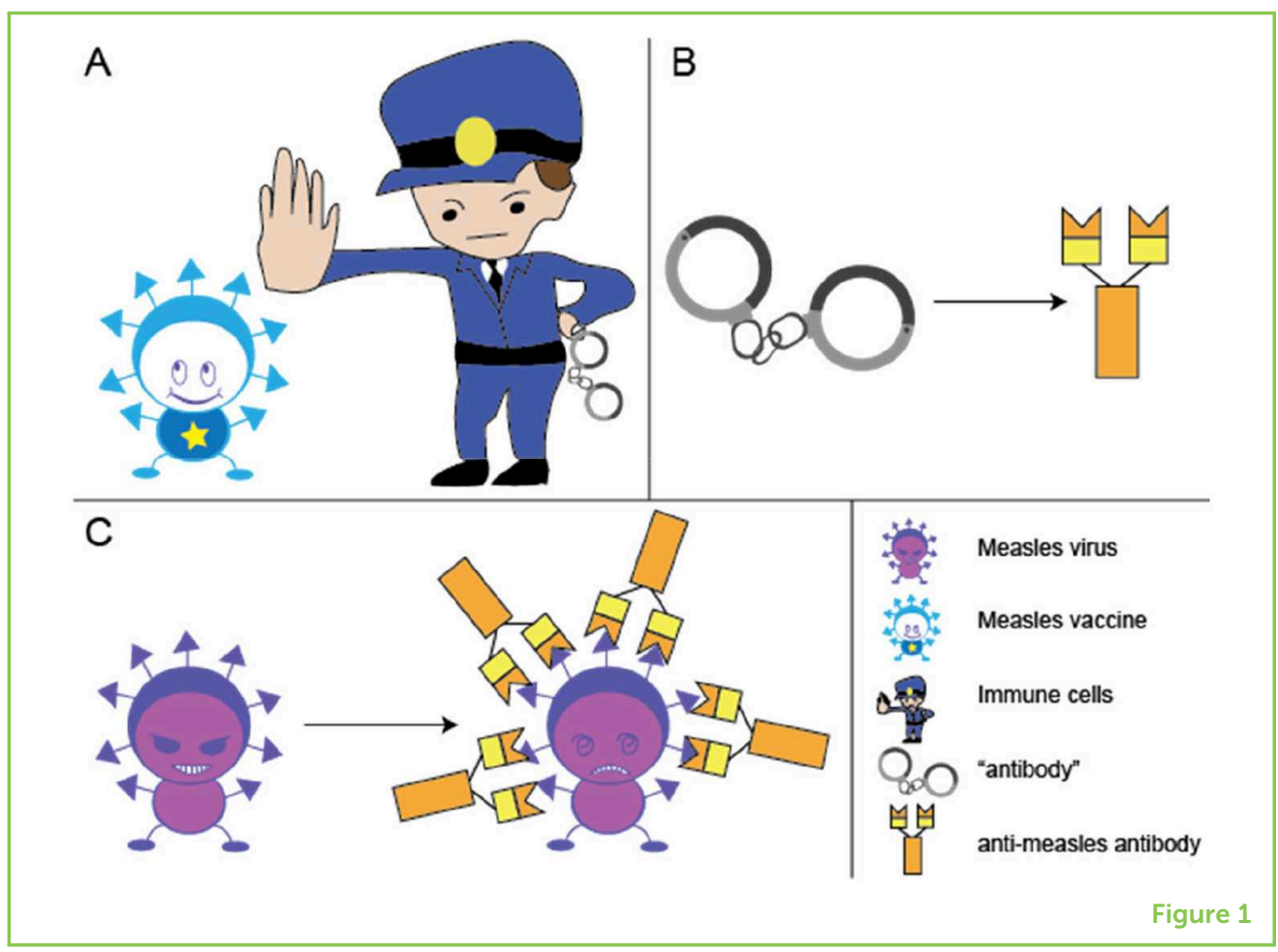

viruses. Biologists call these handcuffs antibodies. Antibodies are large Y-shaped proteins present in the blood, and they can recognize and stick to viruses, making the viruses safe and easy for the body to get rid of. When the immune system arrests a measles virus, it puts handcuffs (antibodies) on it. A handcuffed virus cannot break into the cell and cannot start an infection (Figure 1).

If you have been successfully vaccinated against measles, antibodies that bind to the measles virus will be present in your blood for the rest of your life. If these antibodies ever come across a real measles virus, they react extremely quickly and protect you from getting sick.

Before the measles vaccine was introduced in 1963, there were measles outbreaks infecting more than 3 million kids each year. Every year, tens of thousands of kids were hospitalized and more than 1,000 died from measles infection. Even today, in some countries like Afghanistan and Brazil, which struggle to distribute the measles vaccine, there are severe outbreaks and many people die of measles.

\section{HAVE NEVER MET ANYONE WITH MEASLES. WHY DO I STILL NEED THE VACCINE?}

Measles is normally rare in western countries. Unfortunately, it is still common in many developing countries. The measles virus is therefore always around, because people travel all over the world. If you are vaccinated against measles, you cannot get sick from it. But how about 
Figure 2

Herd protection protects people who cannot be vaccinated because they are too young or have serious health problems. On the left, you can see how the population of infected zombies would grow if each new zombie infects 15 people. On the right, you see that the vaccinated population protects the most vulnerable people in society who cannot be vaccinated due to very young age or problems with their immune systems.

\section{HERD PROTECTION}

When enough people have been given a vaccine, the disease can no longer spread. This way, vaccinated people protect the few people who cannot be given the vaccine.

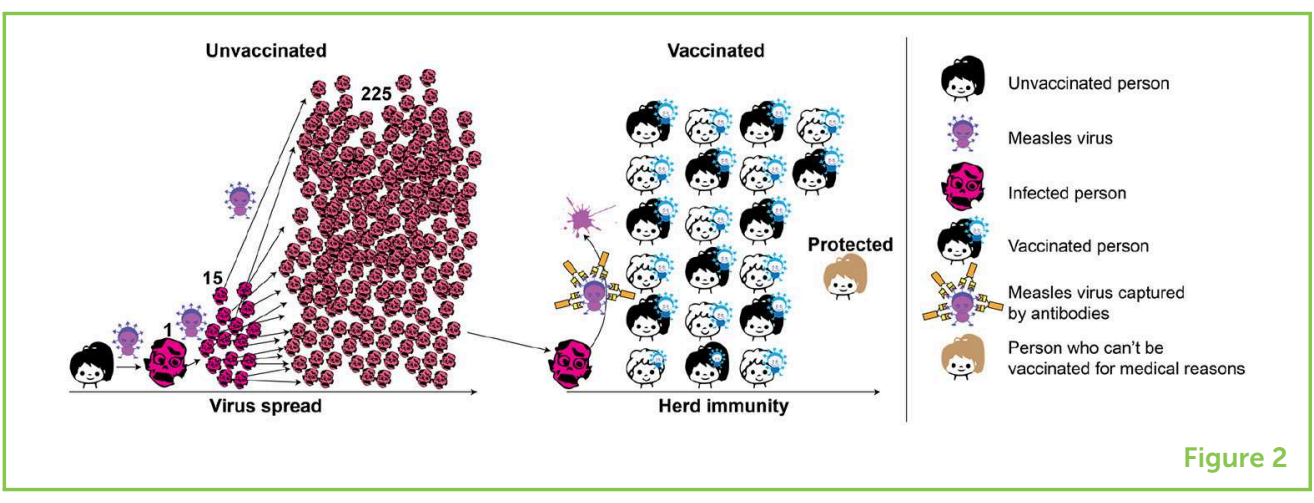

just avoiding people who travel? Would not that work too? The answer is no, and here is why:

In a typical zombie movie, one zombie infects one new person, who infects the next person, and so on-so you have one, then two, then three, then four zombies. Let us imagine what this would look like if the measles virus, breaking into your cells and making you sick, turned you into a zombie! With measles, each infected person infects on average 15 new people, so you have one zombie, then fifteen zombies, then 225 zombies, then 3,375 zombies, and soon, like an explosion, you reach hundreds of thousands of zombies (Figure 2). Measles spreads very, very quickly! Being vaccinated therefore actually does two things: It protects you from becoming sick, and it also prevents you from spreading the disease. If most people who meet the measles virus are protected, we can dramatically reduce the number of new people who become infected, and hopefully the virus will eventually die out completely (Figure 2). This is what we call herd protection. If herd protection is not high enough, we cannot contain outbreaks, and many people are likely to become sick.

Some people are more likely to become very sick from measles but cannot be vaccinated. For example, babies under the age of one, or people whose immune systems do not function properly cannot get the measles vaccine. To protect these people, we need good herd protection: $90-95 \%$ of the total population needs to be vaccinated, which means 18 or 19 of every 20 people. Being vaccinated is not only great for you, you are also doing a great job as a barrier to stop the spread of disease. Your immune system is actually working hard to protect the weakest members of our society, who cannot be vaccinated themselves!

\section{BUT I HEARD THAT THE MEASLES VACCINE COULD BE DANGEROUS ... IS IT?}

Perhaps you have heard that people are afraid that vaccines cause autism? Autism is a mental disorder in which children have difficulties with things like knowing how others are feeling or with using words 


\section{MMR VACCINE}

The combined "Measles, Mumps, and Rubella" vaccine. Mumps and Rubella (also known as German Measles) are two other serious diseases caused by viruses. This vaccine generates protection against all three infections. to express themselves. Very extensive studies in many of countries, involving tens of thousands of patients, have shown that autism has nothing to do with the measles vaccination (or the combined MMR vaccine, which is a vaccine mixture containing the measles vaccine) [3]. So, why do these fears still exist? Largely because it is easy to scare people, and hard to un-scare people.

This story started with a corrupt doctor named Andrew Wakefield in the late 1990s (luckily, corrupt doctors are very rare!). He was doing research on how measles infections (not the vaccine!) might cause problems in the gut. Wakefield was contacted by a lawyer representing the parents of children with autism [4]. The lawyer paid Wakefield a lot of money to produce data showing a link between vaccines and autism [4]. Wakefield examined just 12 children (autism is estimated to affect 1 in 60 children, or more than 1 million children in the USA [5] alone, so 12 is a very small sample)! Despite the tiny number of children tested, and poor evidence, his work was published in a leading medical journal called The Lancet. Dr. Wakefield gave an exaggerated report of his data to the newspapers and television news [4]. The shocking (but fake) news of his findings spread and generated a crisis. Parents were convinced that the measles vaccine was dangerous and stopped vaccinating their children. Herd protection dropped, and measles outbreaks are back in America and Europe [1]. Even though honest scientists have uncovered his many mistakes and his papers have been retracted, the fear still has not gone away. People continue to spread scare stories via the internet. However, just like zombie movies, these stories are never completely true!

\section{DO NOT BE SCARED-GET VACCINATED IF YOU CAN!}

Measles is a serious infectious disease, caused by the measles virus, that spreads extremely fast if not enough people are vaccinated. A vaccine, by definition, is a dead or weakened form of the microorganism. A vaccine will never be worse for you than encountering the real infection. The only exception is if you have a severe allergy to a vaccine ingredient. In this case, you also belong to the small fraction of the population who cannot be vaccinated, and you will need the herd protection of the population to protect you! If you are vaccinated, you can be proud of the work that your immune system is doing to protect you, but also to protect those who are most vulnerable to the infection.

\section{REFERENCES}

1. WHO. 2018. Measles. WHO. Available online at: https://www.who.int/ immunization/diseases/measles/en/

2. Griffin, D. E. 2018. Measles vaccine. Viral Immunol. 31:86-95. doi: 10.1089/vim.2017.0143 
3. Jain, A., Marshall, J., Buikema, A., Bancroft, T., Kelly, J. P., and Newschaffer, C. J. 2015. Autism occurrence by MMR vaccine status among US children with older siblings with and without autism. JAMA 313:1534. doi: 10.1001/jama.2015.3077

4. Deer, B. 2011. How the case against the MMR vaccine was fixed. BMJ 342:c5347. doi: 10.1136/bmj.c5347

5. Baio, J., Wiggins, L., Christensen, D. L., Maenner, M. J., Daniels, J., Warren, Z., et al. 2018. Prevalence of autism spectrum disorder among children aged 8 years-autism and developmental disabilities monitoring network, 11 sites, United States, 2014. MMWR Surveill. Summ. 67:1-23. doi: $10.15585 / \mathrm{mmwr.ss} 6706 a 1$

SUBMITTED: 11 June 2019; ACCEPTED: 23 August 2019; PUBLISHED ONLINE: 11 September 2019.

EDITED BY: Paul-Henri Lambert, Université de Genève, Switzerland

CITATION: Slack E, Arnoldini M, Latorre D, Aslani S, Biagioli V, Cruz T, Dünki NE, Eichelberg ACJ, Goldiger M, Howald N, Marastoni G, Marti T, Peterhans V, Selvakumar $L$ and Winterberg A (2019) Why Is Measles Vaccination so Important? Front. Young Minds 7:119. doi: 10.3389/frym.2019.00119

CONFLICT OF INTEREST STATEMENT: The authors declare that the research was conducted in the absence of any commercial or financial relationships that could be construed as a potential conflict of interest.

COPYRIGHT @e 2019 Slack, Arnoldini, Latorre, Aslani, Biagioli, Cruz, Dünki, Eichelberg, Goldiger, Howald, Marastoni, Marti, Peterhans, Selvakumar and Winterberg. This is an open-access article distributed under the terms of the Creative Commons Attribution License (CC BY). The use, distribution or reproduction in other forums is permitted, provided the original author(s) and the copyright owner(s) are credited and that the original publication in this journal is cited, in accordance with accepted academic practice. No use, distribution or reproduction is permitted which does not comply with these terms.

\section{YOUNG REVIEWERS}

\section{ALAA, AGE: 11}

I love learning. My favorite subject is Science. I am an avid reader and a chocoholic. When I grow up, I want to be a pilot or a scientist. I am a nature fanatic and I love traveling. I have traveled to many fascinating places like Amsterdam, Abu Dhabi, Dubai, Dusseldorf, Frankfurt, London, Vancouver, Victoria and Kelowna and I plan to visit many more in future. I enjoy drawing and coloring, watching cartoons and educational videos. I am a varsity badminton player and I love the game.

\section{FRIESS LAKE ELEMENTARY, AGE: 9}

These zany kids love popcorn, rice krispy treats, and science! 


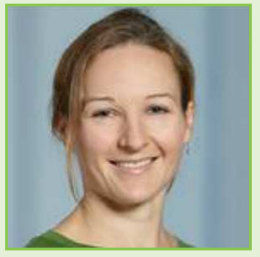

\section{AUTHORS}

\section{EMMA SLACK}

Do you ever wonder about how your immune system can work in your guts? How can we keep the bad bugs out and keep the good bugs in? How does our food affect your health? Can we make effective vaccines that you can swallow? Can we make people and farm animals healthier by changing their gut bacteria? These questions keep my research group and I very busy indeed. We work at ETH Zurich, in Switzerland. I also love to teach and communicate science. This is really important so that everyone, not just the scientists, can keep up to date with the amazing progress that is being made. *emma.slack@micro.biol.ethz.ch

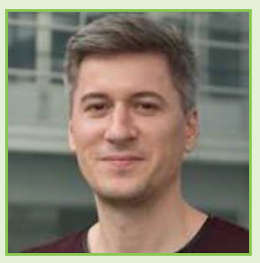

\section{MARKUS ARNOLDINI}

These days, everyone knows that we have tiny microorganisms in (and on) our bodies. They are important for our health, but sometimes also make us sick. I am investigating how our bodies and behaviors select which microorganisms live inside us, and how they interact with each other. Are the "good bugs" always good, or can they sometimes also turn against us and cause diseases? I do this research at ETH Zürich in Switzerland. In addition to doing experiments and analyzing the data, an important part of being a scientist is communicating the results: we are responsible for making sure that our findings reach people and that scientific facts can be used as the basis for making informed decisions by the general public.

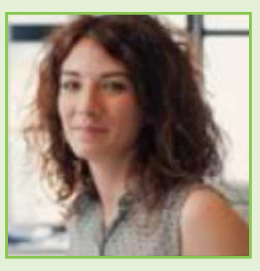

\section{DANIELA LATORRE}

How does the immune system work in the context of infections? Which immune cell population are involved? How can we improve the immune responses to prevent or better treat infections? I have been studying these aspects in healthy individuals and patients affected my immunodeficiencies or autoimmunity. I work at ETH Zurich, in Switzerland. I believe that scientific dissemination to young people and non-scientific community is part of our aim as scientists to help everyone understand science and to avoid spreading of fake news.

\section{SELMA ASLANI}

We are students from all over the world, who are studying for a Masters in Food Sciences, or a Masters in Health Sciences and Technology at ETH Zurich. We all took the class "Food, Microbiota, and Immunity: debating the evidence." This class teaches students to find and read science, to be critical, and to take responsibility for sharing science with the public.

\section{VALENTINA BIAGIOLI}

We are students from all over the world, who are studying for a Masters in Food Sciences, or a Masters in Health Sciences and Technology at ETH Zurich. We all took the class "Food, Microbiota, and Immunity: debating the evidence." This class teaches students to find and read science, to be critical, and to take responsibility for sharing science with the public.

\section{TANIA CRUZ}

We are students from all over the world, who are studying for a Masters in Food Sciences, or a Masters in Health Sciences and Technology at ETH Zurich. We all took the class "Food, Microbiota, and Immunity: debating the evidence." This class teaches 


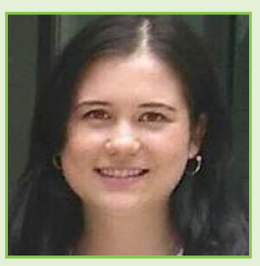
science with the public.

\section{NAOMI ELINA DÜNKI}

We are students from all over the world, who are studying for a Masters in Food Sciences, or a Masters in Health Sciences and Technology at ETH Zurich. We all took the class "Food, Microbiota, and Immunity: debating the evidence." This class teaches students to find and read science, to be critical, and to take responsibility for sharing science with the public.
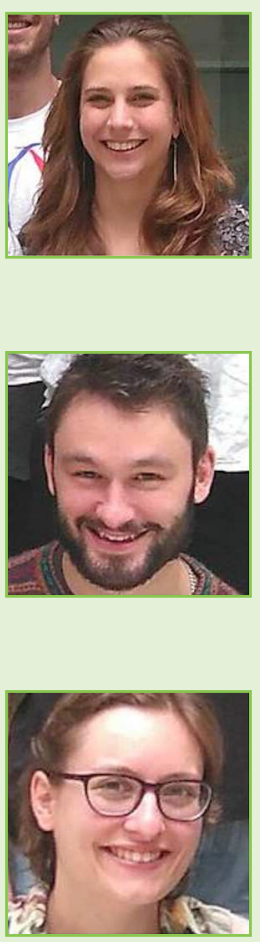

\section{ANTONIA CHIARA JEANNE EICHELBERG}

We are students from all over the world, who are studying for a Masters in Food Sciences, or a Masters in Health Sciences and Technology at ETH Zurich. We all took the class "Food, Microbiota, and Immunity: debating the evidence." This class teaches students to find and read science, to be critical, and to take responsibility for sharing science with the public.

\section{MATTHIAS GOLDIGER}

We are students from all over the world, who are studying for a Masters in Food Sciences, or a Masters in Health Sciences and Technology at ETH Zurich. We all took the class "Food, Microbiota, and Immunity: debating the evidence." This class teaches students to find and read science, to be critical, and to take responsibility for sharing science with the public.

\section{NICOLE HOWALD}

We are students from all over the world, who are studying for a Masters in Food Sciences, or a Masters in Health Sciences and Technology at ETH Zurich. We all took the class "Food, Microbiota, and Immunity: debating the evidence." This class teaches students to find and read science, to be critical, and to take responsibility for sharing science with the public.

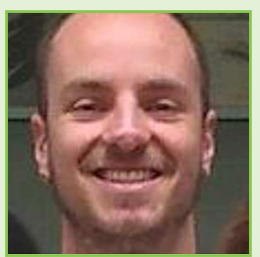

\section{GIOVANNI MARASTONI}

We are students from all over the world, who are studying for a Masters in Food Sciences, or a Masters in Health Sciences and Technology at ETH Zurich. We all took the class "Food, Microbiota, and Immunity: debating the evidence." This class teaches students to find and read science, to be critical, and to take responsibility for sharing science with the public.

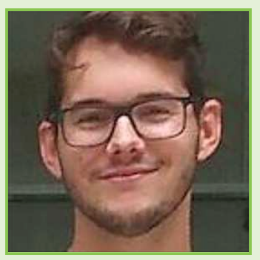

\section{THIERRY MARTI}

We are students from all over the world, who are studying for a Masters in Food Sciences, or a Masters in Health Sciences and Technology at ETH Zurich. We all took the class "Food, Microbiota, and Immunity: debating the evidence." This class teaches students to find and read science, to be critical, and to take responsibility for sharing science with the public.

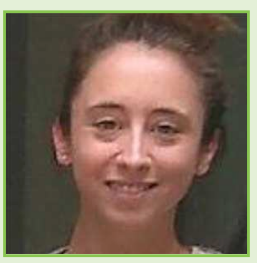

\section{VEGA PETERHANS}

We are students from all over the world, who are studying for a Masters in Food Sciences, or a Masters in Health Sciences and Technology at ETH Zurich. We all took the class "Food, Microbiota, and Immunity: debating the evidence." This class teaches 


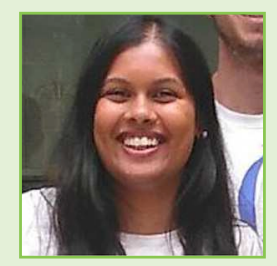

students to find and read science, to be critical, and to take responsibility for sharing science with the public.

\section{LAVANJA SELVAKUMAR}

We are students from all over the world, who are studying for a Masters in Food Sciences, or a Masters in Health Sciences and Technology at ETH Zurich. We all took the class "Food, Microbiota, and Immunity: debating the evidence." This class teaches students to find and read science, to be critical, and to take responsibility for sharing science with the public.

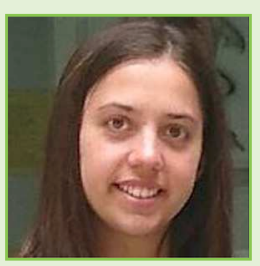

\section{ANNA WINTERBERG}

We are students from all over the world, who are studying for a Masters in Food Sciences, or a Masters in Health Sciences and Technology at ETH Zurich. We all took the class "Food, Microbiota, and Immunity: debating the evidence." This class teaches students to find and read science, to be critical, and to take responsibility for sharing science with the public. 